\title{
ФАРМАКОЛОГИЧЕСКИЙ КОНТРОЛЬ ГЛИКИРОВАНИЯ БЕЛКОВ КАК ПОДХОД К РАЗРАБОТКЕ СРЕДСТВ ЛЕЧЕНИЯ ПОЗДНИХ ОСЛОЖНЕНИЙ САХАРНОГО ДИАБЕТА
}

\author{
А.А. Спасов ${ }^{1,2}$, Р.А. Литвинов ${ }^{1,2}$, Н.А. Гурова', Н.В. Елисеева', \\ Л.В. Науменко', А.И. Ращенко', В.А. Бабкова', В.Л. Русинов \\ С.К. Котовская ${ }^{3}$ И.М. Сапожникова ${ }^{3}$, А.Д. Стрельник ${ }^{4}$ Ю.Г. Штырлин ${ }^{4}$, \\ А.С. Морковник ${ }^{5}$, О.Н. Жуковская ${ }^{5}$, А.К. Брель ${ }^{1}$, С.В. Лисина' \\ 1 ФГБОУ ВО ВолгГМУ Минздрава России, 400131, Россия, Волгоград, \\ пл. Павших Борцов, д 1. \\ 2 ГБУ Волгоградский медицинский научный центр, \\ 400131, Россия, Волгоград, пл. Павших Борцов, д. 1. \\ 3 ФГАОУ ВО УрФУ им. первого Президента России Б.Н. Ельцина, \\ 620002, Россия, Екатеринбург, ул. Мира, д. 17. \\ 4 ФГАОУ ВО КФУ, 420008, Россия, Республика Татарстан, Казань, ул. Кремлевская, д. 18. \\ 5 ФГАОУ ВО ЮФУ, 344006, Россия, г. Ростов-на-Дону, ул. Большая садовая, 105/42.
}

DOI: 10.19163/MedChemRussia2021-2021-79

E-mail:aspasov@mail.ru

Неферментативное гликирование белков, приводящее к образованию межмолекулярных сшивок, является механизмом патогенеза поздних осложнений сахарного диабета (СД). В результате направленного конструирования получены 4-((9-гидрокси3,3,8-триметил-1,5-дигидро-[1,3]диоксепино [5,6-с] пиридин-6-ил)диазенил)фенилсульфонат натрия (совместно с КФУ, г. Казань) (I), моногидрат натриевой соли диэтилового эфира 4-оксо-1,4-дигидропиразоло[5,1-с]-1,2,4-триазин-3,8-дикарбоновой кислоты (совместно с УрФУ, г. Екатеринбург) (II), гидрохлорид 9-бензил-2бифенилимидазо[1,2-а]бензимидазола (совместно с НИИ ФОХ ЮФУ, г. Ростов-на-Дону) (III) а также 1,3-бис(4-метоксибензоил)пиримидин-2,4(1H,3H)-дион (IV).<smiles>Cc1nc(N=Nc2ccc(S(N)(=O)=O)cc2)c2c(c1O)COC(C)(C)OC2</smiles><smiles></smiles><smiles>Clc1ccc(-c2cn3c4ccccc4n(Cc4ccccc4)c3n2)cc1</smiles><smiles>COc1ccc(C(=O)n2ccc(=O)n(C(=O)c3ccc(OC)cc3)c2=O)cc1</smiles>

III

IV

Соединения I, II оказывают антигликирующее действие, в различной степени сочетая его с антигликоксидационной, антиоксидантной, медь-связывающей активностями. Соединения III, IV являются разрушителями поперечных сшивок гликированных белков. В экспериментальной модели СД 1 типа соединения I-IV замедляют развитие микроангиопатии, кардиомиопатии, нефропатии, нейропатии, энцефалопатии, ретинопатии. 